\title{
THE MIDSUMMER HEAT BALANCE OF AN ALASKAN MARITIME GLACIER
}

\author{
By N. A. Streten and G. Wendler \\ (Geophysical Institute, University of Alaska, College, Alaska 997or, U.S.A.)
}

\begin{abstract}
The heat balance of an Alaskan mountain glacier located close to the sea is calculated for a period of $\mathrm{r} 6 \mathrm{~d}$ in midsummer - a period which is typical of the summer in this region in its high cloudiness and in its temperature and humidity conditions. The radiative and the combined sensible and latent heat components are found to contribute equally to the observed high rate of ice melting.

Résumé. L'équilibre thermique en mi-élé d'un glacier maritime de l'Alaska. L'équilibre thermique d'un glacier de l'Alaska situé près de la mer est calculé pour une période de 16 jours en mi-été, période typique de l'été dans cette région en ce qui concerne la fréquence des nuages et les conditions de température et d'humidité. On a trouvé que les constituants radiatifs et la combinaison de la chaleur sensible et latente contribuent à part égale à la rapidité élevée observée de la fonte.

Zusammenrassung. Die hachsommerliche Wärmebilanz eines maritimen Gletschers in Alaska. Für cine 16 tägige hochsommerliche Periode wurde die Wärmebilanz eines nahe dem Meer gelegenen Gebirgsgletschers in Alaska berechnet. Der gefundene hohe Bewölkungsgrad sowie die Temperatur- und Feuchtigkeitswerte sind typisch für den Sommer in dieser Gegend. Die Strahlung und der fühlbare und latente Wärmestrom zusammen, tragen gleichwertig zu der beobachteten, hohen Eisablation bei.
\end{abstract}

\section{INTRODUCTION}

The Worthington Glacier (lat. 61 $10^{\prime}$ N., long. $145^{\circ} 45^{\prime}$ W.) (Fig. 1), is a small mountain glacier with an area of about $8 \mathrm{~km}^{2}$ located in the Chugach Range approximately $28 \mathrm{~km}$ from Valdez in south central Alaska (Fig. 2). The glacier extends from a height of some i $800 \mathrm{~m}$ flowing almost directly eastward with the tongue being located at an elevation of $820 \mathrm{~m}$ within $\mathrm{I}$ km of the Richardson Highway. The Worthington is a small detached part of an extensive glaciated region of the Chugach Range, which feeds a number of very large glaciers, notably the Tazlina, Nelchina, and Columbia, and further to the cast, the smaller Shoup, Klutina, Valdez, and Tonsina glaciers.

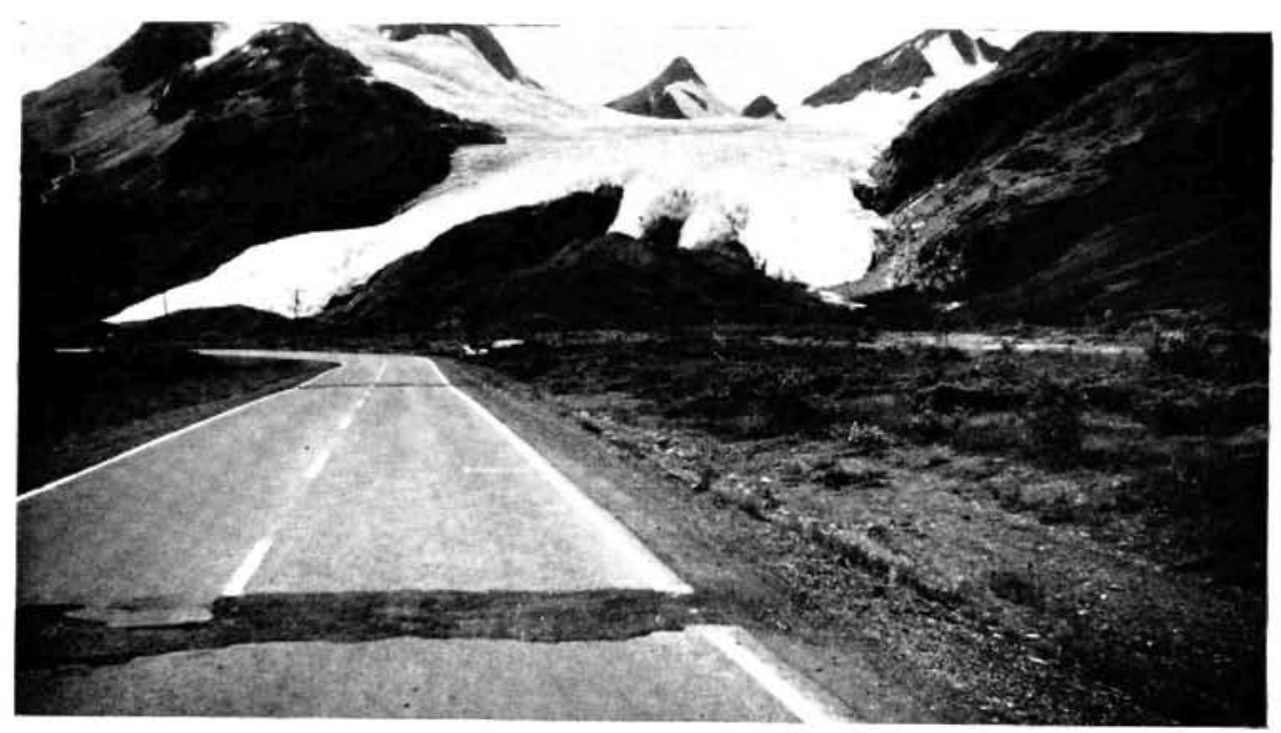

Fig. I. Worthington Glacier, general view looking south. 


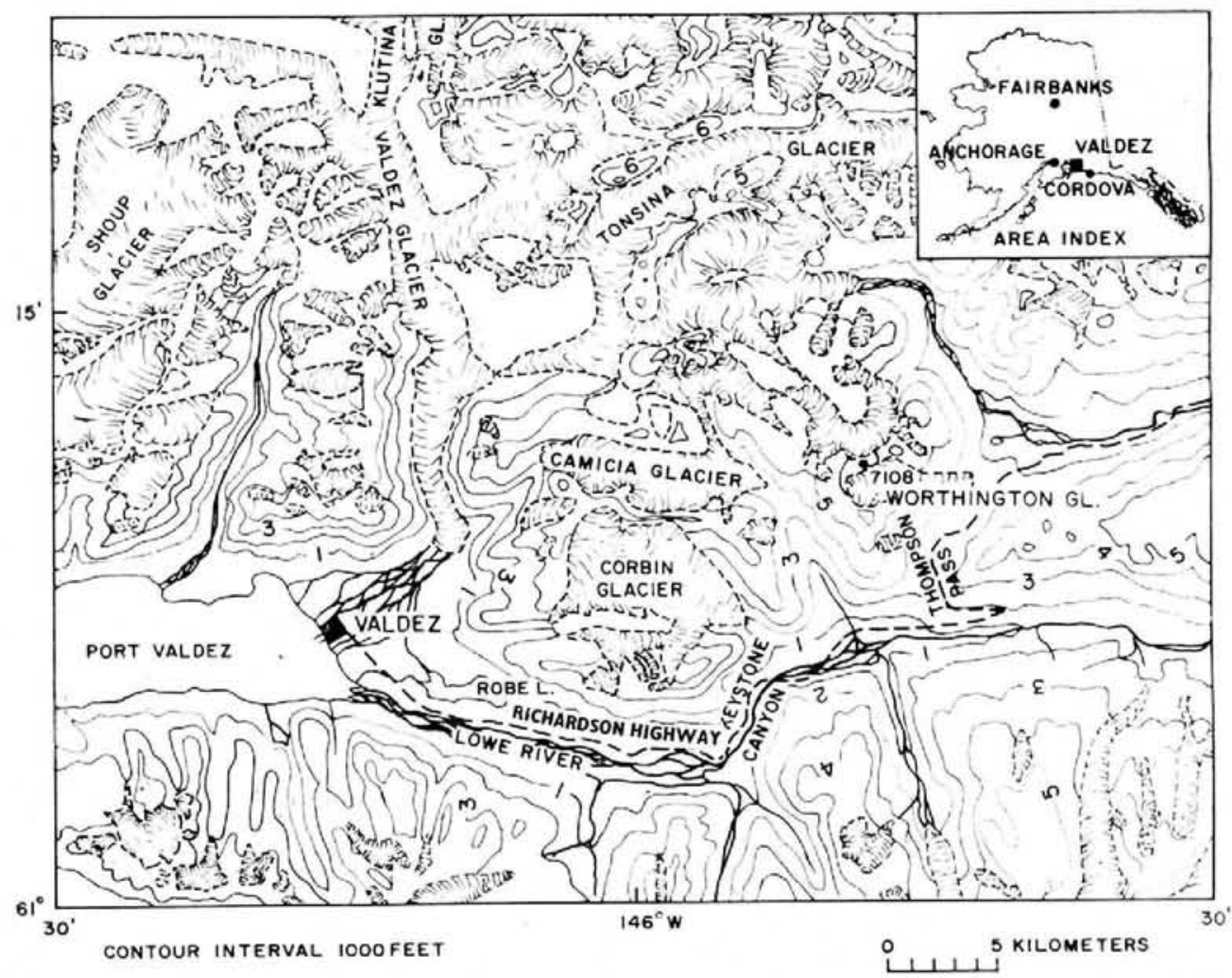

Fig. 2. Location map, south-central Alaska.

The glacier is surrounded entirely either by exposed rock or outwash deposits with the peak immediately to the west of the glacier rising to $2160 \mathrm{~m}$. The region is one of high precipitation. Valdez records a mean annual total precipitation of 62.37 in $(1584 \mathrm{~mm}$ ) of water equivalent, with a maximum in September of 8.4 in $\left(21_{3} \mathrm{~mm}\right)$, while the annual fall at the Thompson Pass, located only a few kilometers from the glacier tongue and at the same elevation is probably in excess of go in $(2286 \mathrm{~mm}$ ). Snowfall depths are recorded in the pass only in the winter months. For the four months November to February, the average over nine years totaled 424.8 in (to $790 \mathrm{~mm}$ ), but individual months have recorded falls over 225 in (5 $710 \mathrm{~mm})$.

In July the normal monthly precipitation at Valdez is 4.72 in $(120 \mathrm{~mm})$ and in June the minimum monthly figure of $2.6 \mathrm{I}$ in $(66 \mathrm{~mm})$ is recorded. It is probable that those months are also those of lowest precipitation in the catchment of the Worthington Glacier.

\section{The Period of Observation and the Instrumentation}

The observation period extended from ${ }_{15} \mathrm{~h}$ on 16 July 1967 , to ${ }_{5} 5 \mathrm{~h}$ on I August 1967 - a duration of 16 whole days.

The meteorological instruments were set up on the tongue of the glacier some $50 \mathrm{~m}$ from the shore of the melt-water lake at its terminus (Fig. 3). The radiation measurements were made with the newly developed $\mathrm{PD}_{4}$ Radiation Balance Meter (Physikalische-Meteorologisches Observatorium-Davos, Switzerland, Fig. 4). This instrument has very nearly the same sensitivity in regions both of short- and long-wave radiation and utilizes Lupolen-a poly- 


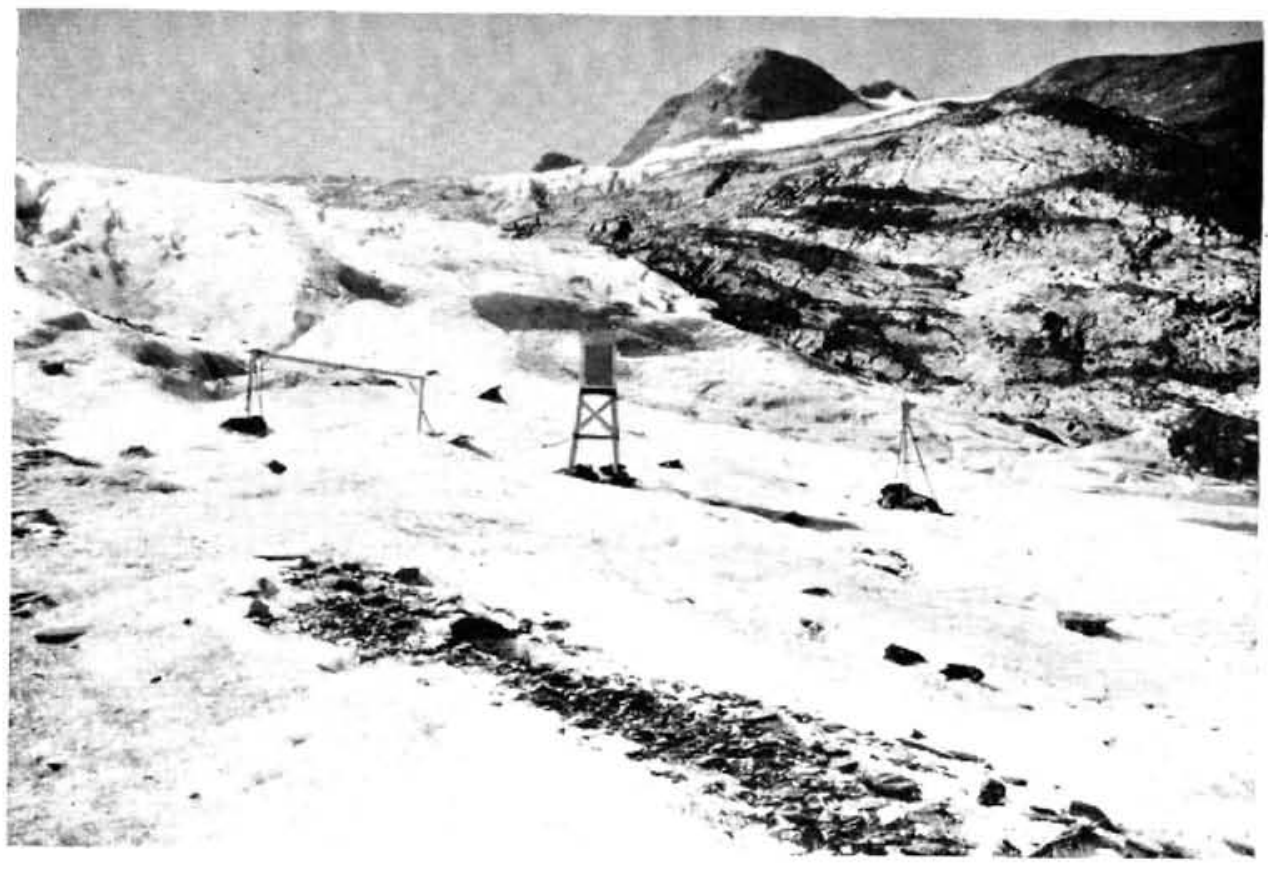

Fig. 3. Instrument expossar, Worthington Glacier.

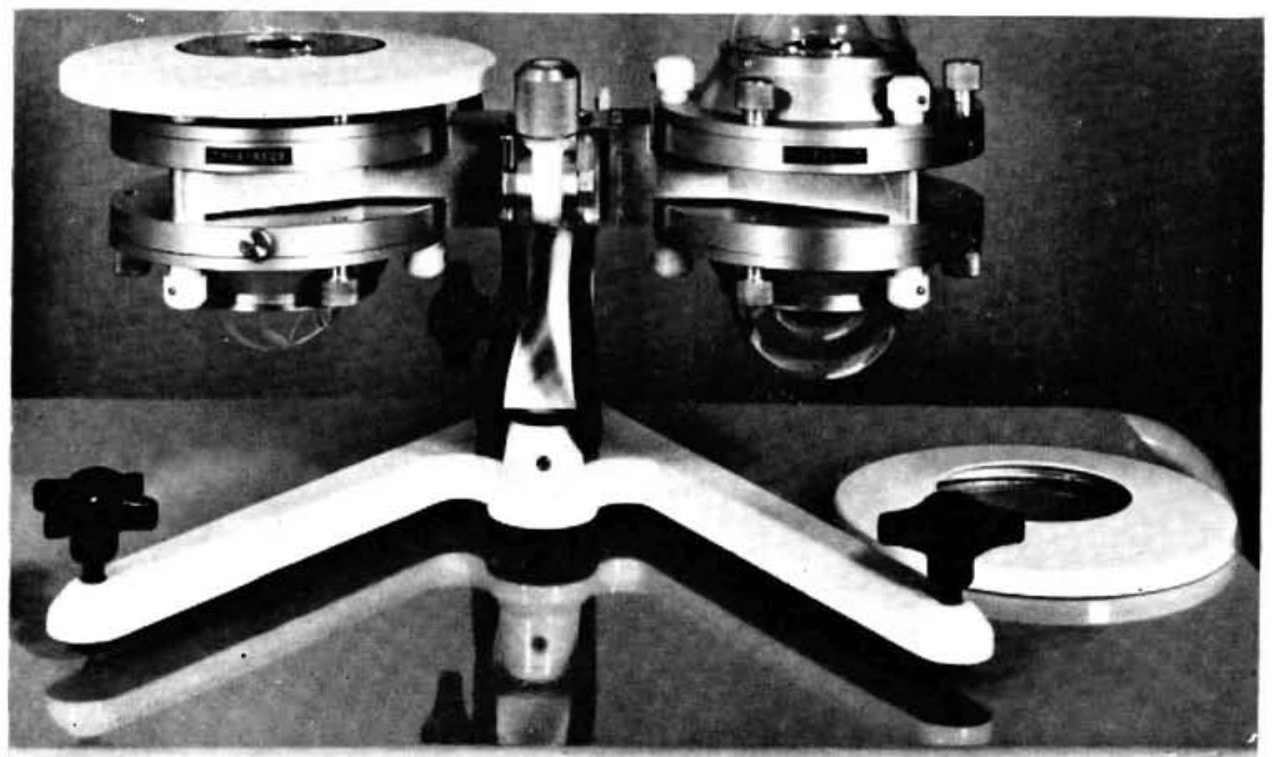

Fig. 4. PD4 Davos radiometer on laboratory stand. Note double glass domes on right and Lupolen shielded sensors on left. 
ethylene product - in the dome shielding the long-wave sensors (Funk, I96I). The instrument has the further advantage that all four receiving surfaces are installed on the same planc metal support, which ensures that the sensors are always parallel to each other. $\Lambda$ t high latitudes, where low sun angles are more frequent, this arrangement has a considerable advantage, since even a small deviation from the horizontal position may result in apparent large differences in the radiation. A six-channel Speedomax recorder was used in conjunction with the radiometer; four channcls for the input from the sensors and one each for the zero point and instrument temperature. A small generator and voltage and phase regulator provided power for the recorder. The radiation instrument had been calibrated by the manufaclurers in the spring of 1967 . However, it was possible to carry out a field calibration over the short-wave range using a standard Linke-Feussner Actinometer and millivolmeter. This was done on the morning of 27 July with the $\mathrm{PD}_{4}$ receiver horizontal. 'I'he calibration constant was found to be unchanged.

A themograph and hygrograph exposed in a louvred screen at a height of $I .4 \mathrm{~m}$ above the ice surface provided a continuous record of temperature and relative humidity. A thermistor and a Bendix carbon hygrometer sensor were also exposed at a height of $0.5 \mathrm{~m}$ and the output recorded on two Esterline-Angus recorders. I'hese instruments were initially compared with the thermograph and hygrograph in the screen, an Assman psychrometer being used as the basic calibration instrument. $\Lambda$ Woefle-type mechanical wind recorcler provided a basic continuous record of average windspeed and direction at a height of $1.9 \mathrm{~m}$ above the ice and was checked for consistency with a second similar instrument exposed at approximately the same height on the edge of the glacier, some $50 \mathrm{~m}$ distant. 'Two portable fan anemometers (Isuzu type) which were initially tested against each other and the Woefle instrument were used in the determination of the wind profiles (see below). The measured ablation was taken as the average reading of four stakes located close to each other near the radiation instrument. The mean deviation of the observed daily ablation values at the individual stakes from the average value of all stakes $(7 \mathrm{~cm})$ was $0.6 \mathrm{~cm}$ or \pm 9 per cent.

\section{Meteorological Conditions during the Period of Observation}

(a) The average and extreme conditions: The mean and extreme conditions observed during the period are tabulated in Table $I$ and the mean daily data in Figure 5.

Table I. Mean and Extreme Meteorological Data, Worthington Gilagier I 6 July To a August 1967

\begin{tabular}{|c|c|c|c|}
\hline Element & Maximum & Minimum & Mean \\
\hline Screen temuperature ${ }^{7} \mathrm{C}$ & $16 . \mathrm{I}$ & 5.6 & 9.6 \\
\hline Screen water vapor pressure $\mathrm{mm} \mathrm{Hg}$ & 10.7 & 6.1 & $7 \cdot 5$ \\
\hline Windspeed $\mathrm{m} \mathrm{s}^{-1}$ & 45 & 1.1 & 2.1 \\
\hline Cloudiness tenths & mo & $\mathbf{I}$ & 8 \\
\hline Daily ablation $\mathrm{cm}$ & 11,2 & $4 \cdot 4$ & 7.0 \\
\hline
\end{tabular}

Notable is the high cloudiness which must be considered typical for this part of Alaska in summer. The average summer cloudiness for Cordova and Valdez, which arc on the coast, is also of the order of 80 per cent. Similar average figures would be expected in the Worthington Glacier area, as it is located in essentially a coastal region close to the crest of the pass across the Chugach Range at this point. 'The low interdiurnal variation in temperature and the high water vapor pressure arc further indicative of the maritime nature of the region, and are what would be expected in the mean at this location when compared with the long-term mean data for summer at Valdez and Cordova and in view of the discussion of Watson (1959). 'The association of the mean daily ablation with the daily mean values of cloudiness, tempcrature, and vapor pressure are evident in Figure 5 . 
(b) Diurnal variations: The mean diurnal variations in the various meteorological elements are given in Table II.

Table II. Diurnal. Variation in Meteorological Conditions, Worthington Glacier 16 Juzy to 1 Aucust 1967

(Based on 3-hourly observation)

\begin{tabular}{lccccc}
\multicolumn{1}{c}{ Element } & Mean maximum & Time & Mean minimum & Time & Mean range \\
Temperature ${ }^{\circ} \mathrm{C}$ & $1 \mathrm{t} .2$ & $12-15 \mathrm{~h}$ & 8.3 & $0-3 \mathrm{~h}$ & 2.9 \\
Water vapor pressure $\mathrm{mm} \mathrm{Hg}$ & 7.9 & $12-18 \mathrm{~h}$ & 7.2 & $3-6 \mathrm{~h}$ & 0.7 \\
Windspeed $\mathrm{m} \mathrm{s}^{-1}$ & 2.7 & $9-12 \mathrm{~h}$ & 1.7 & $18-21 \mathrm{~h}$ & 1.0
\end{tabular}

The low diurnal range of temperature and humidity further indicate the maritime nature of the location. Cloudiness showed no marked diurnal variation, but was possibly slightly higher in the late afternoon. The diurnal variation in ablation was, of course, difficult to determine, but a series of measurements indicated a probable maximum of up to $0.7 \mathrm{~mm} \mathrm{~h}^{-1}$ close to noon and a minimum of $0.1 \mathrm{~mm} \mathrm{~h}^{-1}$ during the night hours.

The period of observation is very short, but it seems that it can be considered fairly typical of the long-term mean conditions over much of the summer in this region.

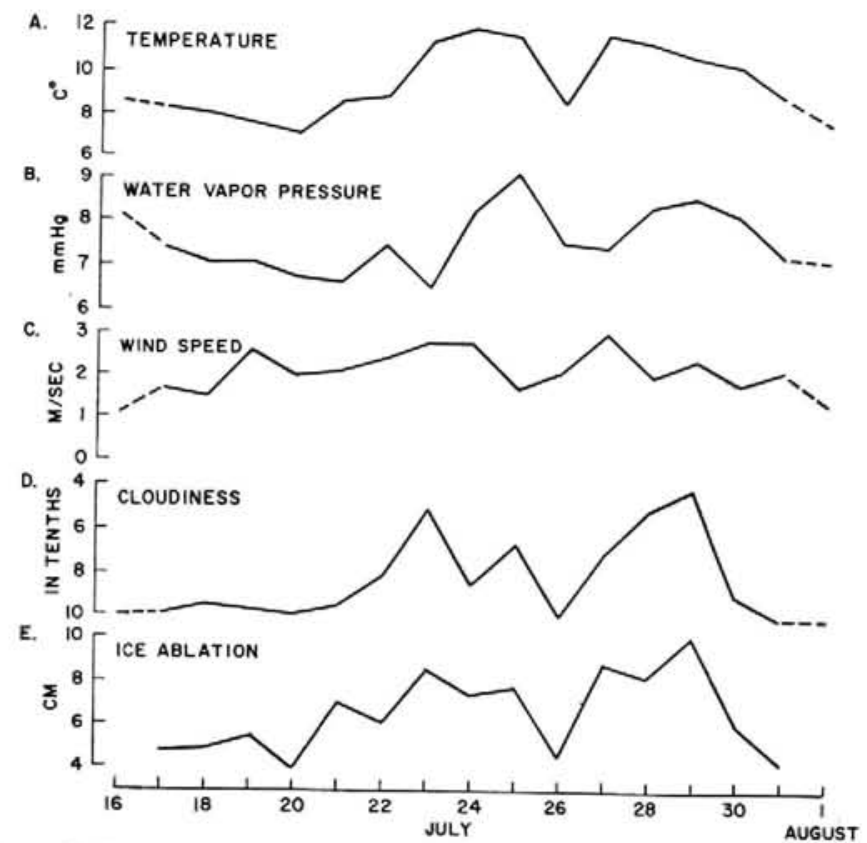

Fig. 5. Daily averages of meteorological elements, Worthington Glacier, summer 1967.

\section{The Heat Bal.ance at the Glacier Surface}

The heat balance has been calculated for individual 24 -hour periods because the melting proceeds throughout the whole day and night. As the glacier tongue can be considered "temperate", there is no heat flux into or out of the glacial ice and in the heat balance equation only three terms need be considered:
(a) the net radiation budget,
(b) the sensible and latent heat flux, and
(c) the ice melt at the surface. 
(a) The net radiation budgel: The mean value of the radiation budget over all wavelengths was measured as $262 \mathrm{cal} \mathrm{cm}^{-2} \mathrm{~d}^{-1}\left(127 \mathrm{~J} \mathrm{~m}^{-2} \mathrm{~s}^{-5}\right)$ or a total of $4 \mathrm{rgo} \mathrm{cal} \mathrm{cm}^{-2}\left(175 \mathrm{MJ} \mathrm{m}^{-2}\right.$ ) for the wholc period of observation. The maximum daily figure was $490 \mathrm{cal} \mathrm{cm}^{-2}(20.5$ $\left.\mathrm{MJ} \mathrm{m} \mathrm{m}^{-2}\right)$ on $29 \mathrm{July}$ and the minimum $\left.13^{2}{\mathrm{cal} \mathrm{cm}^{-2}(5.51 \mathrm{MJ} \mathrm{m}}^{-2}\right)$ on $3^{\mathrm{I}} \mathrm{July}$. The mean value of the long-wave radiation balance over the period was only $-6 \mathrm{cal} \mathrm{cm}^{-2} \mathrm{~d}^{-1}(-3$ $\left.\mathrm{J} \mathrm{m}{ }^{2} \mathrm{~s}^{-1}\right)$. The highest value of $+4 \mathrm{cal} \mathrm{cm}^{-2} \mathrm{~d}^{-1}\left(+2 \mathrm{~J} \mathrm{~m}^{2} \mathrm{~s}^{-5}\right)$ occurred on 30 July, and the minimum of $-39 \mathrm{cal} \mathrm{cm}^{-2} \mathrm{~d}^{-1}\left(-19 \mathrm{~J} \mathrm{~m}^{-2} \mathrm{~s}^{-5}\right)$ on $23 \mathrm{July}$, a day of rclatively low cloudiness. Due to the high mean cloudiness in the period, the long-wave balance is quite often positive as the clouds (usually low $\mathrm{St}, \mathrm{Sc}$, or $\mathrm{Ns}$ ) would frequently have higher radiative temperatures than the $0^{\circ} \mathrm{C}$ of the glacier surface.

Thus for this period of observation the long-wave radiation makes only a very small contribution to the net balance which is dominated by the variations of the short-wave contribution.

A series of measurements of the albedo yielded a mean value of 19 per cent. This is rather low for glacier ice (cf. Dirmhirn and Trojer, 1955) but the Worthington Glacicr ice is rather dirty, being flecked with small chips of glacial debris in many places. In Figure 6 is shown the daily course of the albedo. Higher values are recorded in the mornings and evenings rather

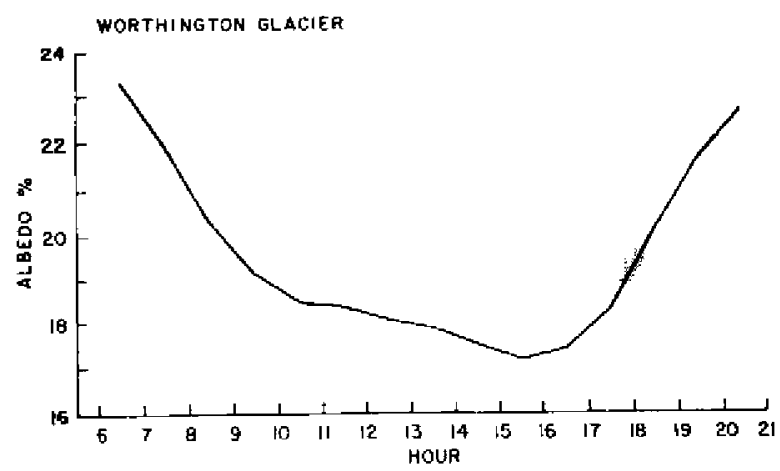

Fig. 6. Daily course of albedo, Worthington Glacier, summer s.967.

than during the main part of the day. $\Lambda$ s the surface is always at melting temperature, this is apparently due to the occurrence of some direct reflection when the sun is at a low angle. This effect agrees with the obscrvations made by Hubley (1957). It was also found that with higher cloudiness the albedo was itself higher. This indicates that the direct solar radiation is absorbed more than the sky radiation. This might be explained in terms of the different distribution of wavelength for direc as opposed to sky radiation, and by the results of $A$ mbach ( 1963 ) that albedo is some function of wavelength. However, the period of olservation is, of coursc, too short and the cloudless periods too few to determinc any clear relation.

(b) The sensible and latent heat fuxes: These fluxes were calculated using Prandtl's relation (Lettau, 1939, 1949). The recording anemometer and the two hand anemometers were used to obtain a number of wind profiles during each day at different times, each profile being based on wind runs over approximately a ten-minute period. Becausc continuous measurement of wind profile was not possible with the anemometers available, it was necessary to calculate a mean value of the roughness parameter $Z_{0}$ based on the mean of all these observations of the profile. The resulting mean value of $Z_{0}$ was 0.18 with an absolute range of from 0.09 to 0.51 . The roughncss parameter was found to be smaller in the night measurements and when conditions were overcast, the surface then being smoother than when exposed to full sunlight. This single value of $Z_{1}$ which was used in all further calculations for the period is in reasonable 
agreement with the observations of Hoinkes (1953) who obtained a mean value of 0.172 in the Alps and Untersteiner ( $195^{8}$ ) who quotes a mean value of 0.15 by night and 0.20 by day for measurements in the Karakoram.

The friction velocity $U_{*}$ was determined from the wind-speed measurements using this mean value of $Z_{0}$ in the equation

$$
\bar{C}_{z}=5 \cdot 75 U_{*} \log \frac{z-z_{0}}{z_{0}},
$$

yielding a value of $U_{*}$ for particular wind speeds of between $6 \mathrm{~cm} \mathrm{~s}^{-1}$ and $26 \mathrm{~cm} \mathrm{~s}^{-1}$.

The eddy diffusivity $K_{\mathrm{a}}$ for adiabatic conditions may then be obtained from the relation

where $\gamma$ is the Kármán constant.

$$
K_{\mathrm{a}}=\rho U_{*} \gamma\left(z_{\mathrm{r}}+z_{\mathrm{o}}\right)
$$

A corrected value $K$ of the eddy diffusivity in non-adiabatic conditions can be obtained from the equation due to Lettau (1949)

$$
K=\frac{K_{\mathrm{a}}}{(\mathrm{I}+x)^{2}}
$$

where $x$ is the dimensionless Richardson number and

$$
x=\frac{g \gamma^{2}\left(Z+Z_{0}\right)^{2}}{T U_{*}{ }^{2}} \frac{\mathrm{d} \theta}{\mathrm{d} z} .
$$

The calculation of the value of $K$ for a height of $1.50 \mathrm{~m}$ yielded values of 0.4 to 1.6 $\mathrm{g} \mathrm{cm}^{-1} \mathrm{~s}^{-1}$ which agree well with the measurements of Ambach (1963), Hoinkes (r953) and Untersteiner ( $\mathrm{I}_{95}{ }^{8}$ ).

If temperature and vapor pressure follow a logarithmic distribution, it can be shown that the sensible heat flow $S$ and the latent heat flow $L$ are given by the equations

and

$$
S=0.24 K t \frac{\mathrm{d} T}{\mathrm{~d} Z}
$$

$L=600 \kappa t \frac{0.62}{P} \frac{\mathrm{d}}{\mathrm{d} z}$.

As no continuous profile measurements were available the assumption of a logarithmic temperature and humidity profile was made in the calculation or $\mathrm{d} T / \mathrm{d} Z$ and $\mathrm{d} e / \mathrm{d} Z$. In this case the expression for the gradients is

where

$$
k_{\mathrm{t}}=\frac{\frac{\mathrm{d} T}{\mathrm{~d} z}=\frac{k_{\mathrm{t}}}{z}}{2 \cdot 3\left(\log Z_{1}-\log Z_{2}\right)},
$$

and similarly for $\mathrm{d} e / \mathrm{d} z$.

Thus, using the values of temperature and relative humidity measured at the two fixed heights above the surface, the gradients of both were derived and the sensible and latent heat fluxes calculated. This was done on a three-hourly rather than a daily basis in order to minimize errors due to the higher wind speeds during the day usually occurring near the time of maximum temperature. The mean and extreme daily values of the fluxes are shown in Table III.

As the air temperature was always above the freezing point, the sensible heat flux was always positive. High humidity and relatively warm temperatures throughout the period resulted in the latent heat being also always positive.

The extreme high values of both the sensible and the latent heat occurred on the warmest day in the period, viz. 24 July, and the lowest values of both also occurred on the same day, 18 July, the day of lowest mean wind speed. 
Table III. Sensible and Latent Heat Fluxes, Worthington Glacier i6 Juty To i August 1967

\begin{tabular}{lrrrr}
\multicolumn{1}{c}{ Flux } & \multicolumn{2}{c}{ Sensible } & \multicolumn{2}{c}{ Latent } \\
& cal cm & $\mathrm{MJ} \mathrm{m}^{-2}$ & $\mathrm{cal} \mathrm{cm}^{-2}$ & $\mathrm{MJ} \mathrm{m}^{-2}$ \\
Daily average & $14 \mathrm{I}$ & 5.9 & 97 & 4.1 \\
Total (16 days) & 2260 & 94.7 & 1550 & 64.9 \\
Maximum daily & 229 & 9.6 & 153 & 6.4 \\
Minimum daily & 86 & 3.6 & 59 & 2.5
\end{tabular}

(c) The observed ice mell: During the whole period $1.12 \mathrm{~m}$ of ice melted requiring 8140 cal $\mathrm{cm}^{-2}$ (340 $\left.\mathrm{MJ} \mathrm{m}^{-2}\right)$, the corresponding daily figures being $70 \mathrm{~mm}$ and $508 \mathrm{cal} \mathrm{cm}^{-2}$ $\left(2 \mathrm{I} .2 \mathrm{MJ} \mathrm{m}^{-2}\right)$. This is a very high ablation, particularly if the high cloudiness of the area is considered.

The heat balance is shown diagrammatically on a daily basis in Figure 7. In Table IV, the

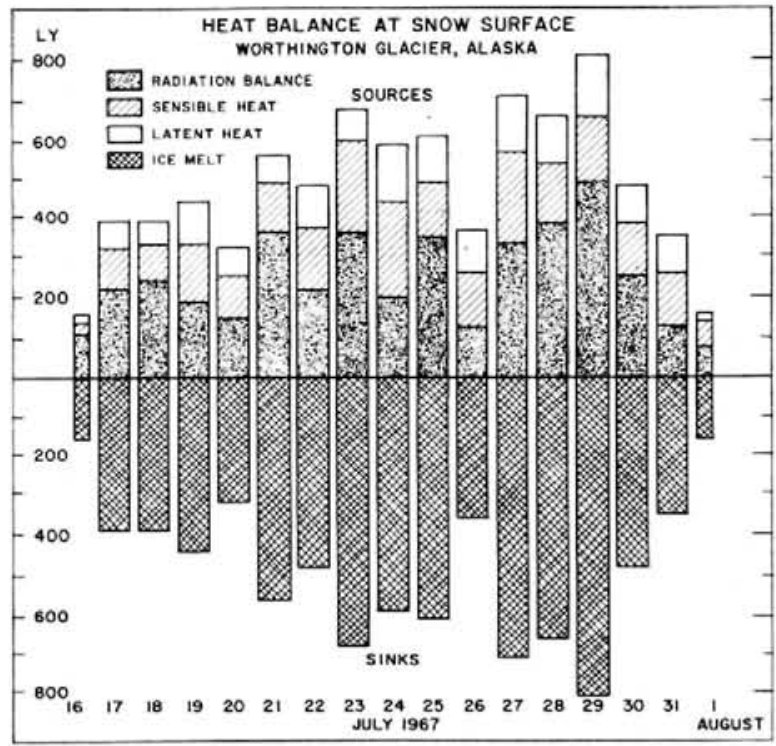

Fig. 7. Heat balance of Worthington Glacier surface, summer 1967.

Table IV. The Components of the Heat Balance, Worthington Glacier 16 July to i August 1967 and Percentage Comparisons

Component

Total

Daily

$$
\text { cal } \mathrm{cm}^{-2} \mathrm{MJ} \mathrm{m}^{-2} \quad \text { cal } \mathrm{cm}^{-2} \mathrm{MJ} \mathrm{m}^{-2}
$$

Radiative

Sensible

$4190 \quad 175$

Latent

$2260 \quad 94$

262

141

11.0

I $55^{\circ}$

65

Melting

$-8140-340$

$\begin{array}{rrrr}97 & 4.1 & 20 & -2 \\ -508 & -21.1 & -100 & -9^{8} \\ - & - & - & -\end{array}$

$\begin{array}{rrrrrr}A & B & C & D & E & F \\ \% & \% & \% & \% & \% & \% \\ 68 & 69 & 78 & 94 & 74 & 86 \\ 32 & 25 & 22 & 6 & 26 & 14 \\ -2 & 6 & -8 & -8 & -74 & -24 \\ -9^{8} & -100 & -84 & -58 & -26 & -54 \\ - & - & -8 & -34 & - & -22\end{array}$

$A=$ Ambach and Hoinkes (1963) (20 days), snow, Alps (Kesselwandferner).

$B=$ LaChapelle (1959) (37 days), snow, Blue Glacier, Washington, U.S.A.

$C=$ Ambach (1963) ( 38 days), ice, Greenland.

$D=$ Untersteiner (196i) (14 days), ice, drifting ice station, Arctic Ocean.

$E=$ Gold and Williams (1961) (14 days), snow, Ottawa, Canada.

$F=$ Wendler (1967) (18 days), snow, Fairbanks, Alaska. 
components of the balance are shown both as totals, and on a daily basis, together with a comparison of the percentage contribution of each term and with that determined by other authors. It should be noted that the comparisons are made on the basis that the total heat input from all sources and the total heat received by all sinks both equal one hundred per cent.

The experiment is subject to a number of errors. The chief difficulty was the absence of a method of obtaining continuous wind profiles for the determination of the variation of $z_{0}$ throughout the period, and in having only two measurements of temperature and relative humidity over the ice surface. The most accurate measurements were those of the radiation balance which, taking into account the several possible sources of error in the measurement system is of the order of \pm 5 per cent. Taking into account the assumed constancy of $Z_{0}$ which affects the values of the eddy diffusivity $K$, as well as the possible errors in the measurement and calculation of the temperature and relative humidity gradients, the calculation of the sensible and latent heat fluxes is considered to be accurate to within \pm 7 per cent. The greatest inaccuracy comes in the measurement of the ablation which is estimated to be only within \pm 9 per cent.

It will be observed in Table IV that a balance is not achieved between the components of the sources and sinks the difference being I.7 per cent. In view of the sources of error mentioned above this value is considered reasonable.

\section{Conclusion}

Several features are of interest in the measurements:

(a) Fifty-one per cent for the net radiative contribution as an energy source is low owing to the high mean cloudiness of over 80 per cent.

(b) Twenty per cent for the latent heat contribution is extremely high owing to the continuous condensation at the relatively high air temperature and humidity experienced in the period.

(c) Twenty-nine per cent for the sensible heat is high, but not excessively so.

In total then, the radiative component and the net eddy heat transfer contribute equally to the ice melting. Comparison of a series of photographs taken at the glacier between 1937 and the present indicate a considerable retreat of the icc. However, they are not sufficiently detailed to permit any numerical assessment of its extent.

\section{ACKNOWLEDGEMENTS}

The authors are grateful to Dr George Cresswell, who assisted in the establishment of the station, and to Physikalisch-Meteorologisches Observatorium, Davos, Switzerland, for permission to reproduce Figure 4. The assistance of Lt O. Balser and the U.S. Army Meteorological Team at Fort Greely, Alaska, is also gratefully acknowledged. The work was supported by the National Science Foundation Grant GA-goo and State of Alaska funds.

\section{MS. received 12 December 1967 and in revised form 28 May 1968}

\section{REFERENCES}

Ambach, W. 1963. Untersuchungen zum Energieumsatz in der Ablationszone des grönländischen Inlandeises. Meddelelser om Grenland, Bd. $174, \mathrm{Nr} .4$.

Ambach, W., and Hoinkes, H. C. ${ }^{1963}$. The heat balance of an Alpine snowfield (Kesselwandferner, $3240 \mathrm{~m}$, Orztal Alps, August 11-Sept. 8, 1958). Union Géodésique et Géophysiqué Intemationale. Association Internationale d'Hydrologie Scientifique. Assemblée générale de Berkeley, 19-8-31-8 1963. Commission des Neiges et des Glaces. p. $24-36$. 
Dirmhirn, I.. and Trojer, E. 1955. Albedountersuchungen auf dem Hintereisferner. Archiv für Meleorologic, Geophysik und Bioklimatologie, Ser. B, Bd. 6, Ht. 4, p. 400-16.

Funk, J. P. 1961. A note on long wave calibration of convectively shielded net radiometers. Archiv für Meleorelogie, Geophysik und Bioklimatologie, Ser. B, Bd. 11, Ht. 1, p. $70-81$.

Gold, L. W., and Williams, G. P. 1961 . Energy balance during the snow melt period at an Ottawa site. Union Géodésique et Géophysique Internationale. Association Internationale d'Hydrologie Scientifique. Assemblée générale de Helsinki, 25-7-6-8 1960. Commission des Neiges et Glaces, p. 288-94.

Hoinkes, H. C. 1953. Wärmeumsatz und Ablation auf Alpengletschern. II. Hornkees (Zillertaler Alpen), September 1951. Geografiska Annaler, Årg. 35, Ht. 2, p. 116-40.

Hubley, R. C. 1957. An analysis of surface energy during the ablation season on Lemon Creek Glacier, Alaska. Transactions. American Geophysical Union, Vol. 38, No. t, p. $68-85$.

LaChapelle, E. R. 1959. Annual mass and energy exchange on the Blue Glacier. Journal of Geophysical Research, Vol. 64. No. 4, p. $443-49$.

Lettau, H. 1939. Atmosphärische Turbulenz. Leipzig, Akademische Verlagsgesellschaft.

Lettau, H. 1949. Isotropic and non-isotropic turbulence in the atmospheric sarface layer. Bedford, Mass., Geophysics Research Directorate, U.S. Air Force Cambridge Research Center. (Geophysical Research Papers, No. 1.)

Untersteiner, N. 1958. Glazial-meteorologische Untersuchungen im Karakorum. II. Wärmehaushalt. Archiv für Meteorologie, Geophysik und Bioklimatologie, Ser. B, Bd. 8, Ht. 2, p. 137-71.

Untersteiner, N. 1961. On the mass and heat budget of Arctic sea ice. Archiv für Meteorologie, Geophysik und Bioklimatologie, Ser. A. Bd. 12. Ht. 2, p. 151-82,

Watson, C. E. 1959. Climate of Alaska. Washington. D.C., U.S. Weather Bureau. (Climatography of the United States, No. 60-49.)

Wendler, G. 1967 . The heat balance at the snow surface during the melting period (March-April 1966) near Fairbanks, Alaska. Gerlands Beiträge zur Geophysik, Bd. 76, Ht. 6, p. 453-6o. 